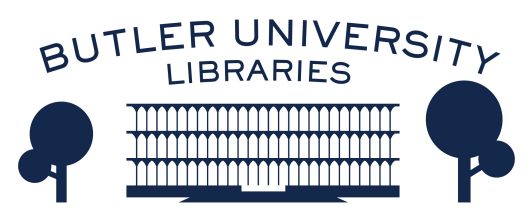

Journal of Hindu-Christian Studies

Volume 4

Article 6

January 1991

\title{
The Poetic Vision of "Walden" and the Idea of Human Freedom in the "Bhagavadgita"
}

Inder Nath Kher

Follow this and additional works at: https://digitalcommons.butler.edu/jhcs

Part of the Religion Commons

\section{Recommended Citation}

Kher, Inder Nath (1991) "The Poetic Vision of "Walden" and the Idea of Human Freedom in the "Bhagavadgita"," Journal of Hindu-Christian Studies: Vol. 4, Article 6.

Available at: https://doi.org/10.7825/2164-6279.1044

The Journal of Hindu-Christian Studies is a publication of the Society for Hindu-Christian Studies. The digital version is made available by Digital Commons @ Butler University. For questions about the Journal or the Society, please contact cbauman@butler.edu. For more information about Digital Commons @ Butler University, please contact digitalscholarship@butler.edu. 


\title{
The Poetic Vision of Walden and the Idea of Human Freedom in the Bhagavadgitta
}

\author{
Inder Nath Kher \\ University of Calgary, Calgary, Canada T2N 1N4
}

\begin{abstract}
IN HIS SEMINAL essay on "Nature" (1836) Emerson writes:

In the woods, a man casts off his years, as the snake his slough, and at what period soever of life is always a child. In the woods is perpetual youth. Within these plantations of God, a decorum and sanctity reign, a perennial festival is dressed, and the guest sees not how he should tire of them in a thousand years.
\end{abstract}

Thoreau's Walden; Or, Life In The Woods (1854) is more than a tribute to Emersonian ideas; it is a forceful plea for the renewal and regeneration of the self. It is concerned with the deeper significance of reality as a whole. It demonstrates that through active and creative participation in the processes of nature one arrives at "the inner meaning of the universe and of human life." Its organic form embodies mythic consciousness and portrays Thoreau's transcendental vision of cosmic unity and oneness. Its archetypal imagery and symbolism are expressive of a syncretic view of the world, which illuminates and harmonizes the polarities of human existence. Invoking the mandala symbols of the sun and the earth, the sky and the pond, Thoreau sharpens our awareness of the underlying relation between light and dark, growth and decay, death and rebirth, time and eternity, and so on. 3

By going into the woods, Thoreau explores and contemplates the essence of human condition. This metaphoric journey into the hinterland of the human mind constitutes Thoreau's continuous struggle to be free from the tyranny of time and a desire to be reborn, to become whole and free like the child who chases butterflies in a meadow. 4 In this process of freedom Thoreau develops "merciless knowledge of himself and selfless understanding of others." $5 \mathrm{He}$ undertakes the practice of meditation (Rajjayoga) and leads a life of utmost simplicity in order to transmute and purify his existence. He cultivates a deliberate life-style and writes with authenticity:

I went to the woods because I wished to live deliberately, to front only the essential facts of life, and see if I could not learn what it had to teach, and not, when I came to die, discover that I had not lived. I did not wish to live what was not life, living is so dear; nor did I wish to practise resignation, unless it was quite necessary. I wanted to live deep and suck out all the marrow of life...

Thus, living deeply, Thoreau identifies with birds, animals, rocks, lakes and ponds, treating the whole of nature "as raw material of tropes and symbols" ${ }^{7}$ with which he describes his life. For him, "a lake is the landscape's most beautiful and expressive feature. It is [the] earth's eye; looking into which the beholder measures the depth of his own nature." 8 The metaphors of experience, such as economy, reading, solitude, beans-planting and housewarming, the images and symbols of circular motion, such as sun, earth, moon, ponds, rivers, leaves, spring and winter, and the central symbol of the Walden Pond, implying wholeness and perfection-all express a profound experience of self-realization in the now and here of time and space. Thoreau believes that man can 
Journal of Hindu-Christian Studies, Vol. 4 [1991], Art. 6

28 Inder Nath Kher

achieve freedom and wholeness in time, but he must have creative imagination to transcend time's linearity/temporality, and a vision to penetrate beyond the surface of things. With prophetic realism, Thoreau writes:

In eternity there is indeed something true and sublime. But all these times and places and occasions are now and here. God himself culminates in the present moment, and will never be more divine in the lapse of all the ages. And we are enabled to apprehend at all what is sublime and noble only by perpetual instilling and drenching of the reality that surrounds us.

And, with poetic vision, he states:

Time is but the stream I go a-fishing in. I drink at it; but while I drink I see the sandy bottom and detect how shallow it is. Its thin current slides away, but eternity remains. I would drink deeper; fish in the sky, whose bottom is pebbly with stars. 10

The earth and the sky meet in Thoreau's imagination, and he reveals the secret of human freedom and wholeness through the religious symbols of fish and water. ${ }^{11}$ Through the language of symbols, Thoreau castigates those who have lost themselves in the prison-house of dead traditions and prejudices which stifle their spiritual and artistic growth. He laments the fact that "most men, through mere ignorance and mistake, are so occupied with the factitious cares and superfluously coarse labours of life that its finer fruits cannot be plucked by them." $12 \mathrm{He}$ exhorts people to economize every moment of their lives, so that they may learn the way of shaping their existence, so that they may become aware of their destiny. To all of them, he says: "Direct your eye right inward, and you'll find/ A thousand regions in your mind/ Yet undiscovered. Travel them, and be/ Expert in home-cosmography." 13 The mood of castigation prevails throughout the narrative; Thoreau warns against the reading of cheap and shallow books, and praises the ancient Classics, the Scriptures of various lands, and the works of the great poets like Dante and Shakespeare. He finds the sounds of nature (birds and animals) more enduring and self-awakening than the echoes of human history and civilization. He recom- mends solitude as a mode of encounter with one's inner reality, enabling one to 'hear beyond the range of sound [and] see beyond the verge of sight'. ${ }^{14}$ He prefers the friendship of seasons to the company of human beings, particularly those human beings who retard one's spiritual freedom. He values human action (Karmayoga) which is performed without any desire for reward or anxiety for its results. He makes a strong case for the life of intellectual and spiritual fulfillment rather than that of instinctive and sensual indulgence. He writes: "We are all sculptors and painters, and our material is our own flesh and blood and bones. Any nobleness begins at once to refine a man's features, any meanness or sensuality to imbrute them." 15 And, above all, Thoreau regards the human imagination as an essential ingredient of man's life which is also his work of art. It is through the creative imagination that Thoreau visualizes the image of his purified self in the Walden Pond. In his creativity, Thoreau perceives the rivers, the woods, the ponds and the meadows as eternal symbols of organic life, as sources of renewal and regeneration, or what Sherman Paul calls "the green flame[s] of life." 16 Through poetic imagination, Thoreau transcends the limits of time and space, and celebrates his vision of simultaneity and unity of all life in the following epiphany:

Thus it appears that the sweltering inhabitants of Charleston and New Orleans, of Madras and Bombay and Calcutta, drink at my well. In the morning I bathe my intellect in the stupendous and cosmogonal philosophy of the BhagavatGeeta, since whose composition years of the gods have elapsed, and in comparison with which our modern world and its literature seem puny and trivial; and I doubt if that philosophy is not to be referred to a previous state of existence, so remote is its sublimity from our conceptions. I lay down the book and go to my well for water, and lo! there I meet the servant of the Brahmin, priest of Brahma and Vishnu and Indra, who still sits in his temple on the Ganges reading the Vedas, or dwells at the root of a tree with his crust and water jug. I meet his servant come to draw water for his master, and our buckets as it were grate together in the same well. The pure 
Walden water is mingled with the sacred water of the Ganges.

In Walden, the art of living by loving and the life of art are identical. Creativity is perfection and redemption; imagination is youth and freedom. The creative process is 'the expansion of the particular into the universal,' of microcosm into macrocosm. ${ }^{18}$ Thoreau's vision of life and art is brilliantly expressed in the allegory of "an artist in the city of Kouroo." The artist's quest for perfection and his self-absorption in the quest liberate him from the bondage of time; he achieves 'perennial youth' and radiant wholeness, and a world with full and fair proportions.

There are many similarities between the poetic sensibility of Walden and the intuitive vision of the Bhagavadgitã. The Gitã teaches us the art of living in harmony with ourselves and with the world that surrounds us through a fourfold structure of yogas or paths, known as Jñannayoga or the path of knowledge, Karmayoga or the path of action, Rājayoga or the path of meditation, and Bhaktiyoga or the path of devotion. Thoreau demonstrates his understanding of the yogas which he practiced throughout the Walden experiment. Thoreau's vision of human freedom and wholeness is indeed consistent with the creative idea of human freedom in the Gitā. In order to be free and whole, man must perform his actions and duties disinterestedly and with a sense of detachment. The Git ä recommends that man should have a sense of non-attachment to sensuous objects even while experiencing them, that he should renounce the desire to enjoy the fruits of actions while doing them (Karma-Phala-Tyãga), and that he should possess an equilibrium of all his mental faculties. The Git $\bar{a}$ says:

But great is the man who, free from attachments, and with a mind ruling its powers in harmony, works on the path of Karma Yoga, the path of consecrated action.... The world is in the bonds of action, unless the action is consecration. Let thy actions then be pure, free from the bonds of desire. ${ }^{19}$

Thoreau was deeply influenced by the Git $\bar{a}$ and perceiving the paradoxical wisdom of the Git $\bar{a}$ he writes:
With thinking we may be beside ourselves in a sane sense. By a conscious effort of the mind we can stand aloof from actions and their consequences; and all things, good and bad, go by us like a torrent. We are not wholly involved in Nature. I may be either the driftwood in the stream, or Indra in the sky looking down on it. I may be affected by a theatrical exhibition; on the other hand, I may not be affected by an actual event which appears to concern me much more. I only know myself as a human entity; the scene, so to speak of thoughts and affections; and am sensible of a certain doubleness by which I can stand as remote from myself as from another. $^{20}$

Both Walden and the Gitã offer spiritual strategies towards free acts of the imagination; both lead to a process of awakening the mind without fixing it on any thing; both encourage what Emerson calls "the original relation with the universe" in which all mean egotism vanishes; and finally, both provide the context of a vision and a perspective which enables one to remain like the persona in Whitman's "Songs of Myself": "Both in and out of the [life's] game and watching and wondering at it."21

\section{Footnotes}

1 Stephen E. Whicher, ed. Selections from Ralph Waldo Emerson, p. 24.

2 Alan W. Watts, Myth and Ritual in Christianity (1954), p. 7. Quoted in Philip Wheelwright, Metaphor and Reality (1962), p. 130.

3 The merging connotations and the paradoxical attributes of the god of light and the Mother Earth cannot be grasped rationally. The sun brings light 'that gives meaning to all things' and symbolizes the spiritual vision, but the sun always comes out of and vanishes into the 'unfathomable darkness.' The Mother Earth gives birth to food which sustains life and symbolizes fertility and growth but she also takes back everything into her dark womb. In nature, however, the opposing forces are always held in a state of balance. See Philip Wheelwright, Burning Fountain, p. 138, and Jacobi, The Psychology of C.G. Jung, p. 97 f.n.

4 Henry Seidel Canby, ed. The Works of Thoreau (Massachusetts: 1937), p. 595 [Selections from the "Journal"].

5 Rudolf Steiner, The Philosophy of Freedom, trans. from the German, and with an Introduction by Michael Wilson, p. xii. There are many similari- 


\section{Inder Nath Kher}

ties between Steiner's idea of human freedom and the concept of freedom in the Bhagavadgita.

6 Brooks Atkinson, ed. Walden \& Other Writings of Henry David Thoreau, pp. 81-82. Thoreau also writes: "I know of no more encouraging fact than the unquestionable ability of man to elevate his life by a conscious endeavour.... Every man is asked to make his life, even in its details, worthy of the contemplation of his most elevated and critical hour." (p. 81).

7 Henry Seidel Canby, ed. The Works of Thoreau, p. 21 [Journal of May 10, 1853].

8 Brooks Atkinson, ed. Walden, p. 168.

9 Ibid., p. 87.

10 Ibid., p. 88.

11 See J.E. Cirlot, $A$ Dictionary of Symbols, pp. 101103 [Fish] \& pp. 345-347 [Water].

12 Walden, pp. 5-6 ["Economy"].

13 Walden, pp. 285-86 ["Conclusion"].

14 In "Solitude," Walden, Thoreau writes: "I find it wholesome to be alone the greater part of the time...I love to be alone. I never found the companion that was so companionable as solitude. We are for the most part more lonely when we go abroad among men than when we stay in our chambers. A man thinking or working is always alone, let him be where he will." (pp. 122-123).

15 Walden, p. 199 ["Higher Laws"].

16 Sherman Paul, "Resolution at Walden," Charles Feidelson, Jr. and Paul Brodtkorb, Jr: eds. Interpretations of American Literature, p. 168.

17 Walden, p. 266.

18 See Edward J. Rose, "A World with Full and Fair Proportions': The Aesthetics and the Politics of Vision," The Western Thoreau Centenary: Selected Papers, ed. J. Gordon Taylor, pp. 45-53.

19 Juan Mascaro, edited with an Introduction, The Bhagavad Gita, pp. 56-57. (Penguin Books 1965)

20 Walden, p. 122.

21 Walt Whitman, "Song of Myself", Section 4. 